\title{
Spatial variation in fungal communities isolated from healthy and diseased sea fans Gorgonia ventalina and seawater
}

\author{
Anabella Zuluaga-Montero*, Carlos Toledo-Hernández, José A. Rodríguez, \\ Alberto M. Sabat, Paul Bayman
}

Department of Biology, University of Puerto Rico-Río Piedras, PO Box 70377, San Juan, Puerto Rico 00936

\begin{abstract}
Sea fans Gorgonia ventalina in the Caribbean are being infected by disease attributed to the fungus Aspergillus sydowii. Little is known about the natural fungal community in sea fans, including spatial variation in community composition and the source of inoculum. Patterns of spatial variation may provide important clues to the source of pathogens and etiology of the disease. The objectives of this study were: (1) to measure spatial variation in the mycoflora associated with diseased and healthy colonies of G. ventalina; and (2) to compare the mycoflora of sea fans with the mycoflora isolated from surrounding seawater. Samples of diseased and healthy sea fan tissue and seawater were collected from coral reefs in Puerto Rico. Fungi were isolated and identified by morphology and sequencing of the nuclear ribosomal internal transcribed spacer region. Twenty-six species of fungi were identified. A. flavus was the most common species isolated from both seawater and sea fan tissue. Higher species richness was found in seawater than in sea fans. Mycoflora of healthy and diseased sea fans differed among sites. Fungal species richness in seawater was higher nearshore than offshore. However, community composition in seawater did not vary spatially. The fungal community of sea fans was not different from that of the surrounding seawater, suggesting low specificity. Our data suggest that the source of offshore mycoflora is the nearshore fungal community, with richness diluted as a result of ocean circulation. Prevalence of aspergillosis was not correlated with fungal species richness but was positively correlated with the number of fungal strains isolated. The fact that diseased fans did not have lower species richness suggests that the disease is not due to a single pathogen, but rather to a variety of opportunistic pathogens.
\end{abstract}

KEY WORDS: Aspergillosis - Aspergillus - Penicillium - Fungi - Coral reefs - Caribbean · Opportunistic pathogen

\section{INTRODUCTION}

Reports of infectious diseases of corals have increased in the last 20 yr (Harvell et al. 1999, Ward \& Lafferty 2004). The implicated pathogen has been identified in only a few cases: white pox of elkhorn coral Acropora palmata has been linked to the bacterium Serratia marcescens (Patterson et al. 2002), bleaching in Oculina patagonica to Vibrio shiloi (Rosenberg \& Falkowitz 2004), and aspergillosis in sea fans to Aspergillus sydowii (Geiser et al. 1998, Kim et al. 2000). However, isolation and identification of pathogens may not be sufficient to understand the dynamics of coral diseases. Several of the microorganisms that have been identified in diseased colonies and implicated in coral diseases have also been found in healthy colonies, suggesting they are part of the normal microflora (Le Campion-Alsumard et al. 1995, Koh et al. 2000, Frias-Lopez et al. 2002, ToledoHernández et al. 2008). Furthermore, some coral diseases are believed to be caused by consortia of microorganisms and not by a single pathogen (e.g. black band disease; Frias-Lopez et al. 2003, Pantos \& Bythell 2006). 
Studies of marine fungi have focused mainly on taxonomy; their ecology and distribution are less understood (Shearer et al. 2007). Most fungal species reported in marine organisms are considered facultatively marine and principally terrestrial (Kendrick et al. 1982, Kohlmeyer \& Volkmann-Kohlmeyer 2003, Shearer et al. 2007). These terrestrial fungi can find their way to coral reefs as a result of runoff or Sahara dust deposition (Shinn et al. 2000, Weir-Brush et al. 2004); little is known about their ubiquity and roles in marine ecosystems. Moreover, spatial variation of these microbial populations is even less understood. To put diseases of corals in an etiological context, it is essential to understand the microflora not only of the hosts, but also of the environment surrounding the hosts (Frias-Lopez et al. 2002), and the relationship between disease prevalence and microflora present. This approach may allow the elucidation of host selectivity and may explain the spatial and temporal variability of coral diseases (Bruno et al. 2003, Harvell et al. 2007).

In this study, we measured the spatial variation (i.e. differences among reefs) of the culturable mycoflora associated with diseased and healthy sea fans Gorgonia ventalina in Puerto Rico and compared it to that of the surrounding seawater. The following questions were addressed. (1) Does the mycoflora of healthy sea fans vary among reefs? (2) Is the same level of spatial variation found in diseased sea fans as in healthy sea fans? (3) Is the fungal community in sea fans in nearshore reefs different from offshore reefs? (4) How similar are the fungal communities in sea fans and the surrounding seawater? (5) Is aspergillosis prevalence correlated with fungal community composition?

High spatial variation should be expected in the mycoflora of healthy sea fans and seawater, because local events such as precipitation, runoff, and currents will cause variations in the arrival of inoculum. Low spatial variation in mycoflora composition would be expected in diseased sea fans due to a dominance of pathogen(s). We expect the nearshore mycoflora to be distinct and richer than offshore due to the influence of terrestrial sources. Assuming that seawater is the reservoir of the pathogen (Geiser et al. 1998) and that there is low specificity of sea fans for fungi, we expect high similarity between seawater and sea fan mycoflora. Even if other pathogens can cause aspergillosis, we would expect that these pathogen(s) will be dominant and that the diversity of other microorganisms will therefore be reduced.

\section{MATERIALS AND METHODS}

Sample collection and culturing. We sampled seawater from 14 coral reefs around Puerto Rico from July to mid-September 2006 (Fig. 1). The nearshore sites were $50 \mathrm{~m}$ to $10 \mathrm{~km}$ from the coast; sites less than $5 \mathrm{~km}$ from shore were Escambrón on the north coast, Fajardo, Cayo Largo, Palominito Island, Icacos Island, and Piñeros Island on the east coast, and Jobos on the southeast coast; sites 5 to $10 \mathrm{~km}$ from the coast were Cayo Diablo and Cayo Lobo on the east coast and Humacao on the southeast coast. In addition to these near-shore sites, we collected at 4 islands off Puerto Rico: Luis Peña, Culebrita, Vieques, and Mona, at 30, 40 , and $35 \mathrm{~km}$ off the east coast, and $68 \mathrm{~km}$ off the southwest coast, respectively.

Three samples of water were collected near $(<5 \mathrm{~m})$ the sea fan colonies at each site. Samples were collected in $250 \mathrm{ml}$ sterilized bottles, refrigerated, and processed within $24 \mathrm{~h}$. In the laboratory, fungi were concentrated by filtering water with sterile nitrocellulose membranes of $0.45 \mu \mathrm{m}$ pore size (Fisher Scientific). The filters were cultured in petri plates containing glucose peptone yeast agar (GPYA) with 3.3 salt, a standard medium to isolate marine fungi (Kohlmeyer \& Kohlmeyer 1979; see also Holler et al. 2000, Koh et al. 2000, Toledo-Hernández et al. 2007a). Preliminary tri-

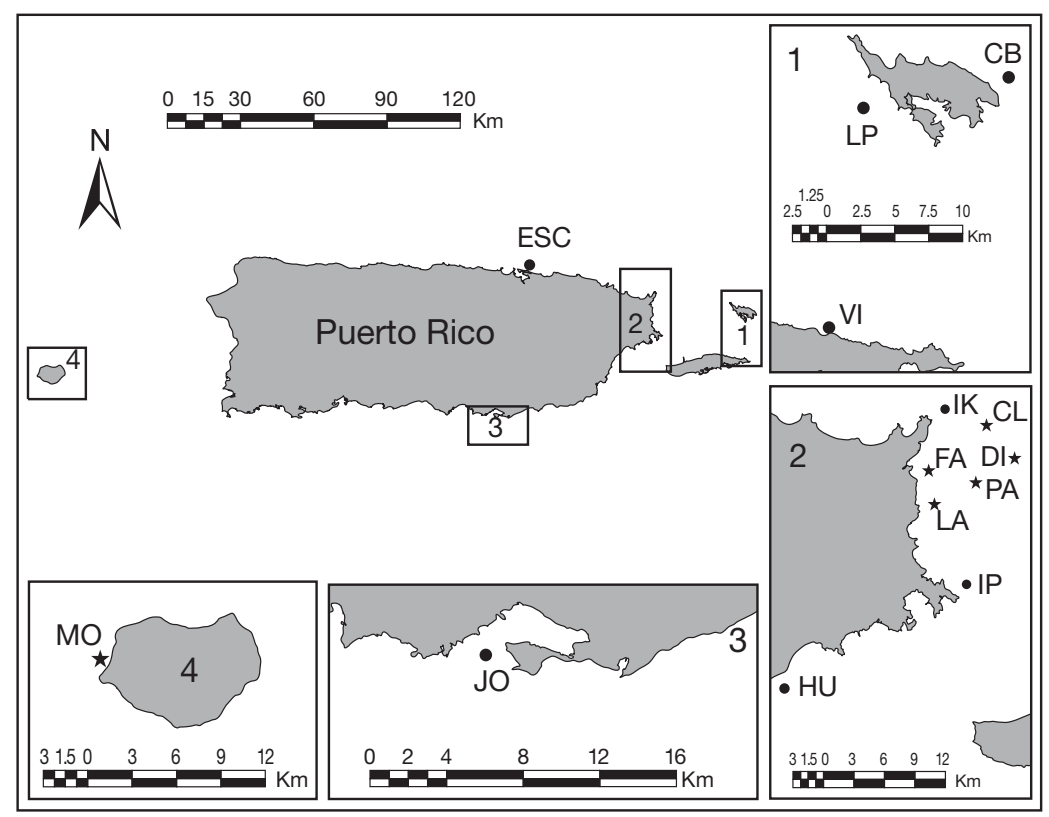

Fig. 1. Puerto Rico, showing the study sites. Seawater collection sites are represented by stars, and sea fan tissue (healthy and diseased) collection sites are represented by black circles. Each box shows an amplified view of the geographic region of the sampling site. ESC: Escambrón. (1) CB: Culebrita, LP: Luis Peña, VI: Vieques Island. (2) IK: Icacos, IP: Piñero Island, CL: Cayo Lobo, DI: Cayo Diablo, PA: Palomino Island, FA: Fajardo, LA: Cayo Largo, HU: Humacao (3) JO: Jobos Bay, (4) MO: Mona island 
als with other culture media yielded fewer fungi, but all media favor some organisms over others. The plates were incubated at $25^{\circ} \mathrm{C}$ and observed for fungal growth weekly for 1 mo. All fungi observed were transferred to new plates of GPYA to obtain pure isolates. These isolates were transferred to liquid medium (potato-dextrose broth) for DNA extraction. All fungi isolated grew in both media.

We sampled tissue of Gorgonia ventalina from midAugust to mid-September 2006. Tissue was collected from 8 reefs at the same time as water samples were taken, as described above (Escambrón, Isla Piñeros, Jobos, Humacao, Icacos, Luis Peña, Culebrita, and Vieques; Fig. 1). Tissue fragments $\left(10 \mathrm{~cm}^{2}\right)$ from 5 healthy colonies and from 5 diseased colonies were collected at each site, for a total of 80 tissue samples. Diseased tissues were distinguished as areas of necrosis surrounded by purple halos (Petes et al. 2003). Samples were collected in $50 \mathrm{ml}$ sterilized tubes, refrigerated, and processed within $24 \mathrm{~h}$ of collection. Fragments were cut into small pieces (1 to $3 \mathrm{~cm}^{2}$ ), surface-sterilized in ethanol 70 for $30 \mathrm{~s}$, and then washed in distilled autoclaved water for $30 \mathrm{~s}$. The samples were cultured (1 fragment per plate), and fungi were isolated as described above.

DNA extraction, amplification and sequencing. DNA was extracted using a Plant Mini Extraction Kit (Qiagen Sciences). The nuclear ribosomal internal transcribed spacer (ITS) region was amplified using primers ITS1F and ITS4 (White et al. 1990, Gardes \& Bruns 1993). Samples were run with a PCR amplification profile used to amplify Aspergillus from coral tissue (Griffin et al. 2002). DNA sequences were corrected with Sequencher 4.9 (Genes Code) and used for BLAST searches in GenBank. When the top 3 matching BLAST hits were from the same species, this species name was assigned to the culture. In almost all cases, the top BLAST hit had $\geq 95$ similarity to the query sequence, and most had $\geq 98$.

Prevalence of aspergillosis. Health status of sea fans was monitored at the same time seawater and sea fan tissues were sampled. Six reefs were chosen: Icacos, Culebrita, Humacao, Jobos, Piñeros, and Vieques. At these reefs, 3 transects $(5 \times 2 \mathrm{~m})$ were marked, and every colony of Gorgonia ventalina was photographed and its health status recorded. In total, 448 colonies were tagged. Diseased colonies were defined as having areas of necrosis surrounded by a purple halo (Petes et al. 2003). Lesions of unknown origin were counted separately (type 2 lesions, Toledo-Hernández et al. 2007b).

Data analysis. Species accumulation curves were used to determine if sampling was sufficient to characterize the culturable fungal community in seawater and sea fan tissue. Multivariate statistical analyses were conducted using Primer 6 software (Plymouth Marine Lab; Clarke \& Gorley 2006) to test for differences in the fungal communities among reefs and between tissue and seawater. The similarity of each of these fungal communities was analyzed using Bray-Curtis similarity coefficients with presence-absence data. One-way analysis of similarity (ANOSIM) was done to test for differences in dissimilarities of the fungal communities of healthy and diseased sea fans among reefs (Clarke \& Warwick 2001). Post-hoc analyses of similarity percentage (SIMPER) were used to determine the contribution of each fungal species for those communities that were significantly different. The fungal communities in sea fan tissues were compared with a 1-way ANOSIM with a combination of factors to test for differences between healthy and diseased tissue and among reefs (Clarke \& Warwick 2001). The fungal community in seawater was analyzed with 1-way ANOSIM grouping reefs within the nearshore and offshore criteria. The distance from the mainland (nearshore versus offshore) was used as the categorical factor for comparison.

A Bray-Curtis analysis was also performed to compare the fungal communities between seawater and sea fan tissue (healthy and diseased). Eight reef sites were included as replicates using presence-absence data. One-way ANOSIM was used to determine the significance of similarities among sources (seawater versus tissue). The SIMPER analysis was used to identify the species contributing most to the dissimilarity.

Chi-square analyses were used to test differences in prevalence of aspergillosis among sites. Correlation analyses were done to determine associations between disease prevalence and fungal composition, and between prevalence and total number of fungal colonies isolated in diseased sea fans.

\section{RESULTS}

Fungal diversity and sampling. In total, 26 taxa of culturable fungi were identified: 23 from seawater and 15 from sea fan colonies, with 12 taxa shared (GenBank accession numbers EU645653-EU645743). The species accumulation curves for healthy and diseased tissue approached an asymptote (Fig. 2a,b), and the jackknife index indicated that sampling effort was sufficient to characterize the culturable fungal community. However, for seawater, the curve did not saturate, indicating that the fungal community in seawater is richer and more sampling effort is needed to fully characterize it (Fig. 2c).

Fungal community in healthy sea fans. Of the 15 species of fungi isolated from sea fan tissue, 13 were found in healthy tissue. The genus Aspergillus was the most diverse, with 6 species. A. flavus and A. sydowii 

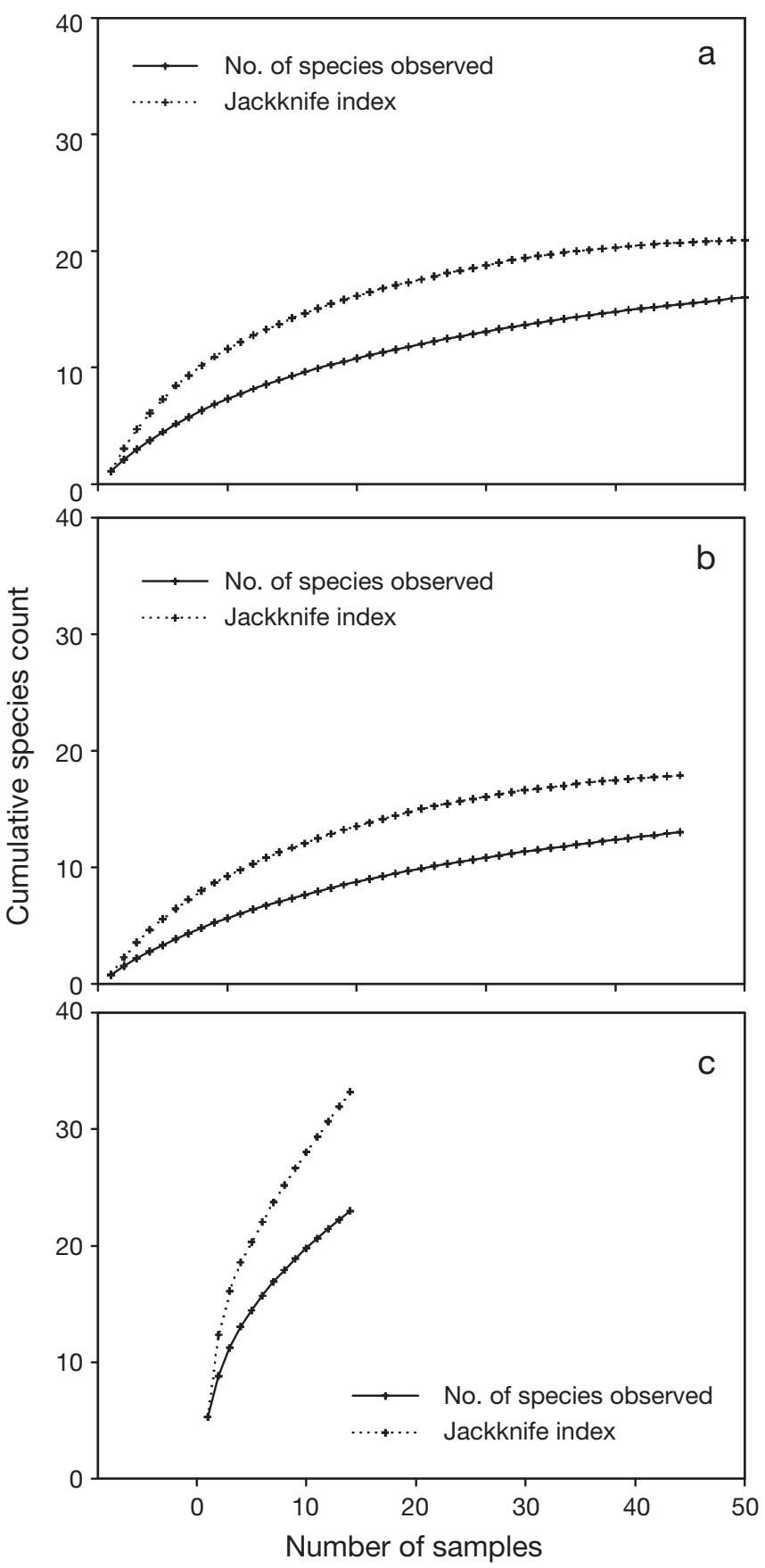

Fig. 2. Species-accumulation curves and jackknife estimators for fungi isolated from (a) healthy tissue, (b) diseased tissue of sea fans, and (c) seawater collected from coral reef sites

were present at 5 and 4 of the sampled sites, respectively (Table 1). The presence of most other fungi was restricted to 1 to 3 sites.

Significant differences were found in the fungal community of healthy colonies among sites (ANOSIM, $\mathrm{R}=0.174, \mathrm{p}=0.004)$. Jobos showed significant dissimilarities with Humacao and Luis Peña. Aspergillus flavus, A. niger, and Cladosporium sp. contributed most to these dissimilarities (Table 2a). Other significant dissimilarities were found between Humacao and Luis Peña, and Humacao and Escambrón, where $A$. niger and Penicillium citrinum contributed most to the dissimilarities, while A. flavus, $A$. niger, and A. sydowii contributed to the dissimilarities between Culebrita and Humacao. Thus, even the most common species contributed to differences among sites.

Fungal community in diseased sea fans. The diversity of isolated fungi was low, and it was common to find singleton species not shared with diseased colonies in other reefs (Table 1). Surprisingly, Aspergillus sydowii was not isolated from diseased tissue from any reef, and A. flavus was the only species shared in 6 out of the 8 reefs.

There were significant differences among sites in the fungal community in diseased tissue (1-way ANOSIM, $\mathrm{R}=0.383, \mathrm{p}=0.003$ ). Jobos showed significant dissimilarities with Icacos and Luis Peña (SIMPER analysis). Aspergillus flavus, Gloeotinia temulenta, and Penicillium citrinum were the main species that contributed to these dissimilarities (Table $2 \mathrm{~b}$ ).

In each reef, fungal community composition did not differ significantly between healthy and diseased tissue. However, there were significant interactions between reef and health state (1-way ANOSIM, combined factors: tissue-site, $\mathrm{R}=0.279, \mathrm{p}=0.001$ ). According to the SIMPER analysis, healthy colonies from Jobos showed significant dissimilarities with diseased colonies from Piñeros and Icacos. Likewise, diseased colonies from Jobos showed significant dissimilarities with healthy colonies of Piñeros and Humacao. Aspergillus flavus, Cladosporium sp., and Gloeotinia temulenta were the most important species contributing to these dissimilarities (Table 2c).

Fungal community in seawater. We isolated 23 species of fungi in 6 genera from seawater (Table 3). Water from Escambrón showed the lowest diversity (1 species) and Palominito Island the highest (10 species). As in sea fans, Aspergillus was the most diverse genus (9 species). Twenty-two species were found in the seawater of nearshore reefs; Penicillium citrinum, A. aculeatus, A. sydowii, A. tamarii, and Cladosporium sp. were the most common. Only 9 species were found offshore (A. flavus and Penicillium sp. were the most common), and almost all offshore species were shared with nearshore reefs (Table 3). More species were shared among sites in seawater than were shared among sea fans. No significant difference in fungal communities isolated from nearshore and offshore seawater was found (ANOSIM, R $=0.088, \mathrm{p}=0.244$ ).

Comparison of fungal communities among seawater and diseased and healthy sea fans. Ten species were shared among seawater and diseased and 
Table 1. Fungal species isolated from diseased (D) and healthy tissue (H) from Gorgonia ventalina at different reef sites. Dashes indicate that species were not found at those sites

\begin{tabular}{|c|c|c|c|c|c|c|c|c|}
\hline \multirow[t]{2}{*}{ Species } & \multirow[b]{2}{*}{$\begin{array}{l}\text { Piñeros } \\
\text { Island }\end{array}$} & \multirow[b]{2}{*}{ Jobos } & \multirow{2}{*}{$\begin{array}{c}\text { Nearshore reefs } \\
\text { Humacao }\end{array}$} & \multirow{2}{*}{ Icacos } & \multirow[b]{2}{*}{ Escambrón } & \multirow[b]{2}{*}{$\begin{array}{l}\text { Luis } \\
\text { Peña }\end{array}$} & \multicolumn{2}{|c|}{ Offshore reefs } \\
\hline & & & & & & & $\begin{array}{l}\text { Culebrita } \\
\text { Island }\end{array}$ & $\begin{array}{l}\text { Vieques } \\
\text { Island }\end{array}$ \\
\hline Aspergillus aculeatus & - & $\mathrm{H}, \mathrm{D}$ & - & - & - & - & - & - \\
\hline A. flavus & $\mathrm{D}$ & $\mathrm{H}, \mathrm{D}$ & $\mathrm{D}$ & $\mathrm{H}$ & $\mathrm{H}, \mathrm{D}$ & - & $\mathrm{H}, \mathrm{D}$ & $\mathrm{H}$ \\
\hline A. niger & - & $\mathrm{H}$ & $\mathrm{H}$ & - & - & - & - & - \\
\hline A. ochraceus & - & - & - & - & - & $\mathrm{D}$ & - & - \\
\hline A. sydowii & - & - & $\mathrm{H}$ & $\mathrm{H}$ & - & $\mathrm{H}$ & $\mathrm{H}$ & - \\
\hline A. tamarii & - & - & - & - & $\mathrm{D}$ & $\mathrm{H}$ & - & - \\
\hline A. terreus & - & - & - & - & - & - & $\mathrm{D}$ & - \\
\hline A. versicolor & - & - & - & - & $\mathrm{H}$ & - & $\mathrm{D}$ & - \\
\hline Cladosporium sp. & $\mathrm{H}$ & $\mathrm{H}$ & - & $\mathrm{H}$ & - & - & - & - \\
\hline C. cladosporioides & - & $\mathrm{D}$ & - & $\mathrm{H}$ & - & - & - & $\mathrm{H}$ \\
\hline Gloeotinia temulenta & $\mathrm{H}, \mathrm{D}$ & - & $\mathrm{H}$ & $\mathrm{D}$ & - & - & - & - \\
\hline Penicillium citrinum & - & - & $\mathrm{H}$ & - & $\mathrm{H}, \mathrm{D}$ & $\mathrm{H}, \mathrm{D}$ & - & - \\
\hline Penicillium sp. & $\mathrm{H}$ & $\mathrm{H}$ & - & - & - & - & - & - \\
\hline Stachybotrys chartarum & - & - & - & - & - & - & - & $\mathrm{H}$ \\
\hline Tritirachium sp. & - & - & - & - & - & $\mathrm{H}, \mathrm{D}$ & - & - \\
\hline
\end{tabular}

healthy tissues, with Aspergillus flavus being the most common species in both seawater and sea fan tissues. Other shared species were A. aculeatus, A. ochraceus, A. niger, A. sydowii, A. tamarii, A. versicolor, Penicillium sp., P. citrinum, and Cladosporium sp. (Fig. 3). No significant differences were found between the fungal communities from healthy sea fans and seawater (ANOSIM, R = -0.011, $\mathrm{p}=0.48$ ). Likewise, differences between diseased sea fans and seawater were not significant (ANOSIM, $\mathrm{R}=0.141, \mathrm{p}=0.091$ ).

Disease prevalence and its relationship with fungal community composition. Disease prevalence was relatively low in all sites ( 0 to $17.5 \%$ ), and the variation among sites was marginally significant $\left(\chi^{2}=9.93\right.$; $\mathrm{df}=5 ; \mathrm{p}=0.07$; Table 4). Culebrita had the highest disease prevalence, while Jobos had the lowest. Prevalence of disease (including type 2 lesions) at the last monitoring period correlated marginally with total number of fungal species isolated from diseased sea fans $(R=0.76, n=6, p=0.07)$.

\section{DISCUSSION}

\section{Fungal diversity}

All of the fungi isolated in this study were first described as terrestrial, although they have also been reported from seawater (Kohlmeyer \& VolkmannKohlmeyer 2003). The most frequent species were Aspergillus flavus, A. sydowii (found only in healthy sea fans), and Penicillium citrinum. This result is consistent with previous studies in Puerto Rico (ToledoHernández et al. 2007a, 2008). Other culture-based studies have reported Penicillium as ubiquitous in different gorgonian species (Koh et al. 2000) and both Aspergillus and Penicillium in scleractinian corals (Kendrick et al. 1982). Also, Penicillium, along with other genera such as Cladosporium, Fusarium, and Acremonium, are frequently found associated with sponges (Holler et al. 2000). It appears that these fungi are successful at colonizing different hosts and are common in many marine organisms.

Greater diversity probably would have been revealed by using direct amplification of DNA from sea fans and seawater instead of culturing, since microorganisms that do not grow in culture could thus have been identified (Bayman 2007). However, the ratio of non-culturable to culturable species appears to be far lower for fungi than for bacteria; in some groups of endophytic fungi in leaves, higher diversity was revealed by culturing than by direct amplification (Arnold et al. 2007). Direct amplification also has limitations: DNA extraction methods and use of specific PCR primers have inherent biases against certain taxa. The best option for fungal diversity studies is to combine direct amplification and culturing approaches (Bayman 2007). This is particularly applicable to obligate marine fungi, which are largely undescribed (Pang \& Mitchell 2005). Fungal taxa that are not represented in molecular databases are difficult to identify using BLAST searches, and some sequences deposited in these databases have questionable taxonomic identifications (Bridge et al. 2003). Although the methods used here overrepresented the frequency of Aspergillus and Penicillium relative to non-culturable fungi, comparisons among tissues, substrates, and reefs were not biased because the same methods were used consistently. 
Table 2. (a) Similarity percentage (SIMPER) analysis for fungal communities in healthy sea fans among sites. Significance was determined by analysis of similarity (ANOSIM) followed by pairwise test comparison. (b) SIMPER analyses for significant ANOSIM between fungal communities isolated from diseased tissue in Gorgonia ventalina by reef sites. Significance was determined by ANOSIM. (c) SIMPER analyses for significant ANOSIM of fungal communities between healthy $(\mathrm{H})$ and diseased (D) tissue of sea fans among sites. Pairwise comparisons that were not significant are not shown

\begin{tabular}{|c|c|c|c|c|}
\hline $\begin{array}{l}\text { Pai } \\
\text { (sig } \\
\text { lex }\end{array}$ & $\begin{array}{l}\text { rwise test } \\
\text { ynificance } \\
\text { vel in \%) }\end{array}$ & $\begin{array}{c}\text { Average } \\
\text { dissimilarity } \\
(\mathrm{SIMPER}, \text { in \%) }\end{array}$ & $\begin{array}{c}\text { Species } \\
\text { promoting } \\
\text { dissimilarity }\end{array}$ & $\begin{array}{c}\text { Contribution } \\
(\%)\end{array}$ \\
\hline \multicolumn{5}{|c|}{ (a) Healthy sea fans } \\
\hline Jobos-Humacao & 0.8 & 94.4 & $\begin{array}{c}\text { Aspergillus flavus } \\
\text { A. niger }\end{array}$ & $\begin{array}{l}33.12 \\
19.21\end{array}$ \\
\hline Jobos-Luis Peña & 0.2 & 100 & $\begin{array}{c}\text { A. flavus } \\
\text { Cladosporium sp. }\end{array}$ & $\begin{array}{c}35 \\
18.33\end{array}$ \\
\hline $\begin{array}{l}\text { Humacao-Luis } \\
\text { Peña }\end{array}$ & 5.4 & 90.8 & $\begin{array}{l}\text { A. niger } \\
\text { Penicillium citrinum }\end{array}$ & $\begin{array}{c}29.38 \\
22.6\end{array}$ \\
\hline $\begin{array}{l}\text { Humacao- } \\
\text { Escambrón }\end{array}$ & 5.6 & 94.7 & $\begin{array}{c}\text { A. niger } \\
\text { P. citrinum }\end{array}$ & $\begin{array}{l}29.38 \\
22.60\end{array}$ \\
\hline $\begin{array}{l}\text { Culebrita- } \\
\text { Humacao }\end{array}$ & 5.4 & 92.2 & $\begin{array}{l}\text { A. flavus } \\
\text { A. niger } \\
\text { A. sydowii }\end{array}$ & $\begin{array}{l}26.51 \\
25.90 \\
24.70\end{array}$ \\
\hline \multicolumn{5}{|c|}{ (b) Diseased sea fan tissue } \\
\hline Jobos-Icacos & 4.8 & 100 & $\begin{array}{l}\text { A. flavus } \\
\text { aloeotinia temulenta }\end{array}$ & $\begin{array}{l}41.67 \\
41.67\end{array}$ \\
\hline Jobos-Luis Peña & 4.8 & 100 & $\begin{array}{c}\text { A. flavus } \\
\text { P. citrinum }\end{array}$ & $\begin{array}{l}41.67 \\
20.83\end{array}$ \\
\hline \multicolumn{5}{|c|}{ (c) Healthy vs. diseased sea fan tissue } \\
\hline $\begin{array}{l}\text { Piñeros (H)- } \\
\text { Jobos (D) }\end{array}$ & 2.4 & 85.07 & $\begin{array}{c}\text { A. flavus } \\
\text { G. temulenta } \\
\text { Cladosporium sp. }\end{array}$ & $\begin{array}{l}29.47 \\
12.85 \\
12.30\end{array}$ \\
\hline $\begin{array}{l}\text { Piñeros (D)- } \\
\text { Jobos (H) }\end{array}$ & 4.5 & 72.84 & $\begin{array}{c}\text { A. flavus } \\
\text { G. temulenta } \\
\text { Cladosporium sp. }\end{array}$ & $\begin{array}{l}37.29 \\
37.29 \\
12.71\end{array}$ \\
\hline $\begin{array}{l}\text { Humacao (H)- } \\
\text { Jobos (D) }\end{array}$ & 0.6 & 100 & $\begin{array}{c}\text { A. flavus } \\
\text { A. niger } \\
\text { G. temulenta } \\
\text { A. aculeatus }\end{array}$ & $\begin{array}{l}34.67 \\
17.33 \\
10.94 \\
10.78\end{array}$ \\
\hline $\begin{array}{c}\text { Icacos (D)- } \\
\text { Jobos (H) }\end{array}$ & 1.8 & 100 & $\begin{array}{c}\text { A. flavus } \\
\text { G. temulenta }\end{array}$ & $\begin{array}{l}40.74 \\
40.74\end{array}$ \\
\hline
\end{tabular}

\section{Spatial variation in the mycoflora of sea fans}

Spatial variation was found in the mycoflora associated with healthy and diseased sea fans. Three reefs were most responsible for the spatial variation in the mycoflora of healthy sea fans: Jobos, Humacao, and Luis Peña. The dissimilarities suggest that local environmental factors may influence the fungal composition of sea fans. Jobos had more fungal species and more isolates than other sites. A possible explanation is that Jobos is an estuary, historically impacted by agricultural runoff and a major sugar cane mill, and cur- rently impacted by the chronic discharge of warm waters from a thermoelectric plant (Robles et al. 2002). Also, Jobos is a large, closed bay with a small entrance, which may limit exchange with adjacent areas and thus promote a distinctive fungal community. In contrast, Humacao and Luis Peña had good water quality (high transparency) and appeared to have little terrestrial influence. However, it is not clear why these 2 sites had a distinctive mycoflora because other sites also shared these attributes. Bruno et al. (2003) found that local increase in nutrient concentrations can increase the severity of disease in sea fans at smaller spatial scales.

The mycoflora associated with diseased sea fan colonies also varied significantly among reef sites. Again, Jobos and Luis Peña were sites that contributed to the spatial variation in diseased colonies. The observed high spatial variation in diseased colonies is contrary to the expectation of dominance by a single (e.g. Aspergillus sydowii) or few pathogens across sites. Rather, it is consistent with the hypothesis that sea fan disease is caused by opportunistic pathogens varying in space and time (Toledo-Hernández et al. 2008).

Studies of bacterial communities of diseased corals (using direct amplification) have also found significant spatial variation, both among geographic areas and at a local scale (Frias-Lopez et al. 2003, Voss et al. 2007). Our results show that this pattern also applies to fungal communities associated with diseased corals, which vary among reefs several kilometers apart. The fact that we also found significant spatial variation among healthy colonies suggests that this variation is characteristic of fungal communities associated with marine organisms in general, not only those associated with diseased colonies.

\section{Differences in the mycoflora between diseased and healthy sea fans}

In this study, differences in the mycoflora between diseased and healthy colonies were more attributable to differences between reefs than to the health of the 
Table 3. Fungi isolated from seawater from different reef sites. Nearshore reefs: LA: Cayo Largo, PA: Palominito Island, DI: Cayo Diablo, CL: Cayo Lobo, HU: Humacao, IK: Icacos Island, IP: Isla Piñeros, JO: Jobos, FA: Fajardo, ESC: Escambrón. Offshore reefs: LP: Luis Peña, MO: Mona Island, VI: Vieques Island, CB: Culebrita. +: presence. -: absence

\begin{tabular}{|c|c|c|c|c|c|c|c|c|c|c|c|c|c|c|}
\hline \multirow{2}{*}{ Species } & \multirow[b]{2}{*}{ LA } & \multirow[b]{2}{*}{ PA } & \multirow[b]{2}{*}{ DI } & \multirow[b]{2}{*}{ CL } & \multicolumn{2}{|c|}{ Nearshore } & \multirow[b]{2}{*}{ IP } & \multirow[b]{2}{*}{ JO } & \multirow[b]{2}{*}{ FA } & \multirow[b]{2}{*}{$\mathrm{ESC}$} & \multirow[b]{2}{*}{ LP } & \multicolumn{2}{|c|}{ Offshore } & \multirow[b]{2}{*}{$\mathrm{CB}$} \\
\hline & & & & & HU & IK & & & & & & $\mathrm{MO}$ & VI & \\
\hline Aspergillus aculeatus & + & + & - & + & - & + & + & + & + & + & - & - & - & + \\
\hline A. flavipes & - & - & - & - & + & - & - & - & - & - & - & - & - & - \\
\hline A. flavus/oryzae & - & - & + & - & - & + & + & - & - & - & + & + & - & + \\
\hline A. japonicus & - & - & - & + & - & - & - & - & - & - & - & - & - & - \\
\hline A. niger group & - & + & - & - & - & + & - & - & + & - & - & + & - & - \\
\hline A. nomius & - & + & - & - & - & - & + & - & - & - & - & - & - & - \\
\hline A. ochraceus & - & - & - & - & - & - & + & - & - & - & - & - & - & - \\
\hline A. puniceus & - & + & - & + & - & - & + & - & - & - & - & - & - & - \\
\hline A. sydowii & + & + & - & + & - & - & + & - & - & - & - & + & - & - \\
\hline A. tamarii & + & + & - & - & - & - & + & + & - & - & + & - & - & + \\
\hline A. terreus & - & + & - & + & - & - & - & - & - & - & - & - & - & - \\
\hline A. tubigensis & - & + & - & - & - & - & - & - & - & - & - & - & - & - \\
\hline A. versicolor & + & + & - & - & + & - & - & - & - & - & - & - & - & - \\
\hline Cladosporium cladosporioides & + & - & - & - & - & - & - & - & - & - & - & - & - & - \\
\hline Cladosporium sp. & - & - & + & + & - & + & - & + & - & - & - & + & + & - \\
\hline Nectria mauritiicola & - & - & - & - & - & + & - & - & - & - & - & - & - & - \\
\hline Penicillium citrinum & - & + & + & + & - & + & - & + & + & - & - & - & + & + \\
\hline P. coprophilum & - & - & - & - & - & - & - & - & + & - & - & - & - & - \\
\hline P. solitum & - & - & - & - & - & - & - & - & - & - & + & - & - & - \\
\hline P. glabrum & - & - & - & - & - & - & - & + & - & - & - & - & - & - \\
\hline Penicillium sp. & + & - & + & + & - & + & - & - & + & - & + & - & + & + \\
\hline Phoma pomorum & - & - & - & - & - & - & - & + & - & - & - & - & - & - \\
\hline Stachybotrys echinata & - & - & - & - & + & - & - & - & - & - & - & - & - & - \\
\hline
\end{tabular}

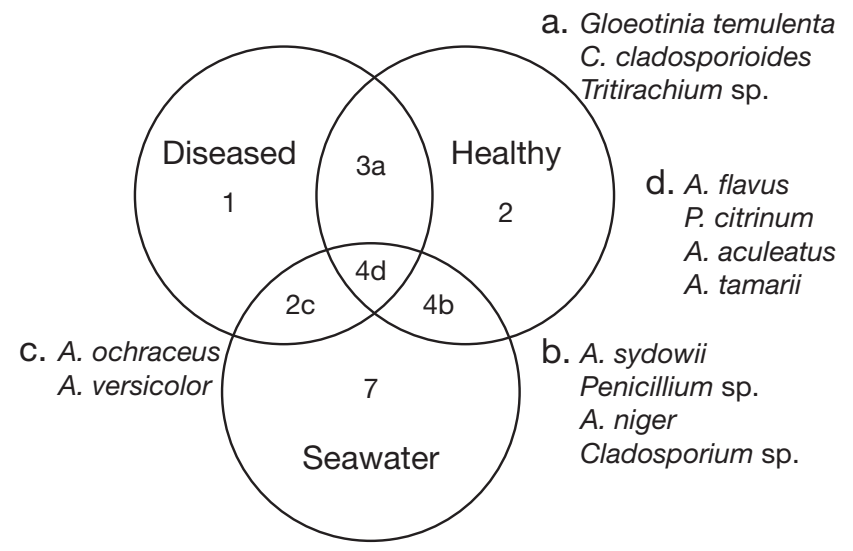

Fig. 3. Shared fungal species among healthy and diseased tissue of sea fans and seawater. Numbers in the overlap between circles represent shared species: (a) healthy and diseased tissue, (b) healthy tissue and seawater, (c) diseased tissue and seawater, (d) diseased and healthy tissue and seawater. Numbers in the big circles represent the number of species not shared. A.: Aspergillus

colony. A parallel study that involved some of the same reefs sampled in this study also found significant differences between fungal communities in healthy and diseased sea fan tissue (Toledo-Hernández et al. 2008). However, that study pooled data from several reefs, and just tested for differences among tissue types. Our results suggest that the differences they observed may have partly been due to differences among reefs rather
Table 4. Percent of aspergillosis prevalence in sea fans for each site. $\mathrm{N}=$ total number of colonies. $\mathrm{M} 1, \mathrm{M} 2$ and $\mathrm{M} 3$ are the percent of prevalence observed during a year of monitoring of the colonies. M1: first monitoring, M2: monitoring after 6 mo, M3: last monitoring after $1 \mathrm{yr}$

\begin{tabular}{|lrrrr|}
\hline Sites & N & M1 & M2 & \multicolumn{1}{c|}{ M3 } \\
\hline Jobos & 29 & 0.0 & 3.4 & 10.34 \\
Humacao & 46 & 4.3 & 4.5 & 4.35 \\
Culebrita & 57 & 17.5 & 20.0 & 17.54 \\
Vieques & 59 & 8.5 & 9.1 & 5.08 \\
Piñeros & 77 & 9.1 & 14.3 & 12.99 \\
Icacos & 180 & 10.0 & 7.7 & 6.67 \\
\hline
\end{tabular}

than differences between healthy and diseased tissue.

In scleractinian corals, bacterial communities differ between healthy and diseased colonies. The bacterial composition in corals may be controlled in part by the coral itself, promoting selectivity (Klaus et al. 2005, Pantos \& Bythell 2006, Ritchie 2006, Rohwer et al. 2002). This same pattern was reported for bacterial communities present in sea fans, where changes were observed between affected and unaffected areas of the same colony, but was not obvious between individual healthy and diseased colonies (Gil-Agudelo et al. 2006). However, this pattern was not observed for fungi. Our study suggests that many fungi found in seawater are successful colonizers of sea fans and provides little evidence for selectivity. 


\section{Spatial variation in the mycoflora in seawater}

The mycoflora was more diverse in seawater than in sea fans. Moreover, the fact that the species accumulation curve for seawater did not show a tendency towards saturation indicates that the mycoplankton community is highly diverse. Sites offshore were less diverse, with most offshore species shared with inshore sites. These shared species explain why the dissimilarity between the inshore and offshore community was not significant. These data suggest that an important source of offshore mycoflora is the inshore community with richness diluted as a result of ocean circulation. This pattern is expected if some of the fungi are terrestrial, and reach the ocean in runoff; it is not expected if the fungi reach the ocean through deposition from clouds of dust, which impact most of the Caribbean, as has been proposed previously (Shinn et al. 2000, Griffin \& Kellogg 2004). Similarly, surveys of inshore and offshore bacterioplankton from Curaçao suggest that differences in the proportion of cyanobacteria found between them may reflect the influence of terrestrial runoff, coastal pollution, or inorganic sedimentation inshore (Frias-Lopez et al. 2003). Distribution and diversity of fungi in open water is largely unexplored (Venter et al. 2004).

Although Aspergillus sydowii is considered the causal agent of aspergillosis in sea fans (Geiser et al. 1998), it is probably an opportunistic rather than a primary pathogen (Toledo-Hernández et al. 2008). Given that $A$. sydowii was not isolated from diseased colonies from any reef in this study (as also reported by ToledoHernández et al. 2008), the so-called sea fan aspergillosis may be caused by other microorganisms as well; it is also possible that in some cases it may be an abiotic disease with no infectious agent, caused by environmental stress (Green \& Bruckner 2000).

\section{Comparison of mycoflora in seawater vs. sea fans}

The similarity between fungi isolated from seawater and sea fans suggests low specificity of sea fans for fungi. Most species found in sea fans were also present in seawater and most were species of Aspergillus. Given the cosmopolitan nature of Aspergillus species in terrestrial environments, their salt tolerance, and the tremendous numbers of conidia they produce, their ubiquity in marine environments is not surprising (Griffin \& Kellogg 2004).

Studies that have related the bacterial community of hard corals and seawater have found more differentiation (Frias-Lopez et al. 2002, Rohwer et al. 2002). Therefore, octocorals may be less selective than scleractinian corals, or fungi may be less specific colonizers than bacteria. The lack of information about whether facultative marine fungi sporulate in the water (Smith et al. 1996, Shinn et al. 2000), or how long the fungi can survive in the water column or in other marine organisms, makes it difficult to determine the functional importance of these fungi in marine ecosystems. However, it is expected that they can disperse rapidly in marine systems, due to strongly directional ocean currents that run along the coastlines (McCallum et al. 2003).

The results of this study suggest that local environmental factors influence fungal composition and that the source of marine fungi may be local terrestrial input, promoting spatial variation of fungal communities. Attempts to isolate Aspergillus sydowii from African dust clouds were unsuccessful (Rypien 2008), casting doubt on African dust deposition as a source of pathogens of sea fans in the Caribbean. Our attempts to isolate $A$. sydowii from dust events that impacted Puerto Rico in 2006 were also unsuccessful (A. Zuluaga-Montero unpubl. data). Thus, it seems that African dust clouds may have been overemphasized as a source of pathogen inoculum for sea fans, although the arrival of inocula will vary with changes in atmospheric conditions (Goudie \& Middleton 2001).

The high spatial variation of the fungal community in sea fans found in this study provides an important insight in understanding sea fan disease. Little is known about spatial variation in marine microbial communities, and techniques commonly used to study terrestrial communities of plants and animals are difficult to apply.

\section{Disease prevalence and fungal composition}

This study supports the hypothesis that sea fan disease is caused by opportunistic pathogens rather than by a primary pathogen. The site with the highest prevalence (Culebrita) was also the site that exhibited the highest number of fungi considered opportunistic pathogens (Aspergillus flavus, A. terreus, and A. versicolor; Abarca 2000). Also, no fungal species at these sites was solely associated with diseased colonies; most were associated with both diseased and healthy colonies. Finally, the marginal correlation between prevalence and fungal richness supports the opportunistic pathogen hypothesis.

New approaches to patterns of local distribution in marine microbial communities would help researchers focus on how local land use practices affect these patterns. Local strategies in terrestrial conservation management may be key for the management of coral diseases as well as for the conservation of coral reef ecosystems in general. 
Acknowledgements. This study was supported by grants from UPR Sea Grant (NOAA award NA16RG2278, project R-92-104), NOAA-CRES (NOAA Award NA170P2919), NIH-SCORE (S06GM08102), and NSF-CREST (HRD0734826). A.Z.M. thanks the International Society for Reef Studies (ISRS) for an ISRS/TOC Coral Reef Conservation Award (2006) and PBDT fellowship (2007) from the Graduate Studies and Research Dean's Office of UPR Río Piedras. Sequencing was done at the UPR Sequencing \& Genotyping Facility, supported in part by NCRR-AABRE Grant no. P20 RR16470, and University of Puerto Rico Biology Department. We are grateful to A. Herrera for assistance in the field, J. Acevedo and A. Bones for assistance in the lab, and C. Zambrana for help with the map. Special thanks to A. Dieppa and Mr. Claudio for help collecting and monitoring of sea fans in Jobos Bay National Estuarine Research Reserve (JOBANER). Comments from A. Cróquer and I. Bejarano greatly improved this manuscript.

\section{LITERATURE CITED}

Abarca ML (2000) Taxonomía e identificación de especies implicadas en la aspergilosis nosocomial. Rev Iberoam Micol 17:S79-S84

Arnold AE, Henk DA, Eells RL, Lutzoni F, Vilgalys R (2007) Diversity and phylogenetic affinities of foliar fungal endophytes in loblolly pine inferred by culturing and environmental PCR. Mycologia 99:185-206

Bayman P (2007) Fungal endophytes. In: Kubicek CP, Druzhinina IS (eds) The Mycota IV. Environmental and microbial relationships. Springer-Verlag, Berlin, p 213-227

- Bridge PD, Roberts PJ, Spooner BM, Panchal G (2003) On the unreliability of published DNA sequences. New Phytol 160:43-48

Bruno JF, Petes LE, Harvell CD, Hettinger A (2003) Nutrient enrichment can increase the severity of coral diseases. Ecol Lett 6:1056-1061

Clarke KR, Gorley R (2006) Primer V5 (\& V6): user manual/ tutorial. PRIMER-E, Plymouth

Clarke KR, Warwick RM (2001) Change in marine communities: an approach to statistical analysis and interpretation, Vol 2. PRIMER-E, Plymouth

Frias-Lopez J, Zerkle AL, Bonheyo GT, Heikoop JM, Fouke BW (2002) Partitioning of bacterial communities between seawater and healthy, black band diseased, and dead coral surfaces. Appl Environ Microbiol 68:2214-2228

Frias-Lopez J, Bonheyo GT, Qusheng J, Fouke BW (2003) Cyanobacteria associated with coral black band disease in Caribbean and Indo-Pacific reefs. Appl Environ Microbiol 69:2409-2413

Gardes M, Bruns TD (1993) ITS primers with enhanced specificity for basidiomycetes - application to the identification of mycorrhizae and rusts. Mol Ecol 2:113-118

Geiser DM, Taylor JW, Ritchie KB, Smith GW (1998) Cause of sea fan death in the West Indies. Nature 394:137-138

Gil-Agudelo DL, Myers C, Smith GW, Kim K (2006) Changes in the microbial communities associated with Gorgonia ventalina during aspergillosis infection. Dis Aquat Org 69: 89-94

Goudie AS, Middleton NJ (2001) Saharan dust storms: nature and consequences. Earth Sci Rev 56:179-204

> Green EP, Bruckner AW (2000) The significance of coral disease epizootiology for coral reef conservation. Biol Conserv 96:347-361

Griffin DW, Kellogg CA (2004) Dust storms and their impact on ocean and human health: dust in earth's atmosphere. EcoHealth 1:284-295
Griffin DW, Kellogg CA, Peak KK, Shinn EA (2002) A rapid and efficient assay for extracting DNA from fungi. Lett Appl Microbiol 34:210-214

- Harvell C, Kim K, Burkholder JM, Colwell RR and others (1999) Emerging marine disease: climate links and anthropogenic factors. Science 285:1505-1510

Harvell C, Jordán-Dahlgren E, Merkel S, Rosenberg E, Raimundo L, Smith G, Weil E, Willis B (2007) Coral disease, environmental drivers, and the balance between coral and microbial associates. Oceanography 20:172-195

> Holler U, Wright AD, Matthée GF, Konig GM, Draeger S, Aust H, Schulz B (2000) Fungi from marine sponges: diversity, biological activity and secondary metabolites. Mycol Res 104:1354-1365

Kendrick B, Risk MJ, Michaelides J, Bergman K (1982) Amphibious microborers: bioeroding fungi isolated from live corals. Bull Mar Sci 32:862-867

Kim K, Harvell CD, Kim PD, Smith GW, Merke SM (2000) Fungal disease resistance of Caribbean sea fan corals (Gorgonia spp.). Mar Biol 136:259-267

- Klaus J, Frias-Lopez JF, Bonheyo GT, Heikoop JM, Fouke BW (2005) Bacterial communities inhabiting the healthy tissues of two Caribbean reef corals: interspecific and spatial variation. Coral Reefs 24:129-137

Koh L, Tan TK, Chou LM, Goh NK (2000) Fungi associated with gorgonians in Singapore. Proc 9th Int Coral Reef Symp 1:521-526

Kohlmeyer J, Kohlmeyer E (1979) Marine mycology: the higher fungi. Academic Press, New York

Kohlmeyer J, Volkmann-Kohlmeyer B (2003) Fungi from coral reefs: a commentary. Mycol Res 107:386-387

- Le Campion-Alsumard T, Golubic S, Priess K (1995) Fungi in corals: symbiosis or disease? Interaction between polyps and fungi causes pearl-like skeleton biomineralization. Mar Ecol Prog Ser 117:137-147

> McCallum H, Harvell CD, Dobson A (2003) Rates of spread of marine pathogens. Ecol Lett 6:1062-1067

Pang KL, Mitchell JI (2005) Molecular approaches for assessing fungal diversity in marine substrata. Bot Mar 48: 332-347

> Pantos O, Bythell JO (2006) Bacterial community structure associated with white band disease in the elkhorn coral Acropora palmata determined using culture-independent 16s rRNA techniques. Dis Aquat Org 69:79-88

- Patterson KL, Porter JW, Ritchie KE, Polson SW, Mueller E (2002) The etiology of white pox, a lethal disease of the Caribbean elkhorn coral, Acropora palmata. Proc Natl Acad Sci USA 99:8725-8730

Petes LE, Harvell CD, Peters EC, Webb AM, Mullen KM (2003) Pathogens compromise reproduction and induce melanization in Caribbean sea fans. Mar Ecol Prog Ser 264:167-171

Ritchie KB (2006) Regulation of microbial populations by coral surface mucus and mucus-associated bacteria. Mar Ecol Prog Ser 322:1-14

Robles PO, Gonzalez GM, Laboy E, Capella J (2002) Jobos Bay estuarine profile: a national estuarine research reserve. Department of Natural and Environmental Resources (DRNA), San Juan, Puerto Rico

> Rohwer F, Seguritan V, Aza F, Knowlton N (2002) Diversity and distribution of coral-associated bacteria. Mar Ecol Prog Ser 243:1-10

Rosenberg E, Falkowitz L (2004) The Vibrio shiloi/Oculina patagonica model system of coral bleaching. Annu Rev Microbiol 58:143-159

Rypien KL (2008) African dust is an unlikely source of Aspergillus sydowii, the causative agent of sea fan disease. Mar Ecol Prog Ser 367:125-131 
Shearer CA, Descals E, Kohlmeyer B, Kohlmeyer J and others (2007) Fungal biodiversity in aquatic habitats. Biodivers Conserv 16:49-67

Shinn E, Smith GM, Prospero JM, Betzer P, Hayes ML, Garrison V, Barber RT (2000) African dust and the demise of Caribbean coral reefs. Geophys Res Lett 27: 3029-3032

Smith GW, Ives LD, Nagelkerken IA, Ritchie KB (1996) Caribbean sea-fan mortalities. Nature 383:487

Toledo-Hernández C, Bones-González A, Ortiz-Vázquez OE, Sabat AM, Bayman P (2007a) Fungi in the sea fan Gorgonia ventalina: diversity and sampling strategies. Coral Reefs 26:725-730

Toledo-Hernández C, Sabat A, Zuluaga-Montero A (2007b) Density, size structure and aspergillosis prevalence in Gorgonia ventalina at six localities in Puerto Rico. Mar Biol 152:527-535

Toledo-Hernández C, Zuluaga-Montero A, Bones-González A, Sabat AM, Bayman P (2008) Fungi in healthy and diseased sea fans (Gorgonia ventalina): Is Aspergillus

Editorial responsibility: Paul Sammarco,

Chauvin, Louisiana, USA sydowii always the pathogen? Coral Reefs 27:707-714

Venter JC, Remington K, Heidelberg JF, Halpern AL and others (2004) Environmental genome shotgun sequencing of the Sargasso Sea. Science 304:66-74

Voss JD, Mills DK, Myers JL, Remily ER, Richardson L (2007) Black band disease microbial community variation on corals in three regions of the wider Caribbean. Microb Ecol 54:730-739

Ward J, Lafferty KD (2004) The elusive baseline of marine disease: Are diseases in ocean ecosystems increasing? PLoS Biol 2:542-547

Weir-Brush J, Garrison VH, Smith GW, Shinn EA (2004) The relationship between gorgonian coral (Cnidaria: Gorgonacea) diseases and African dust storms. Aerobiologia 20: 119-126

White TJ, Bruns TD, Lee SB, Taylor JW (1990) Amplification and direct sequencing of fungal ribosomal RNA genes for phylogenetics. In: Innis MA, Gelfand DH, Sninsky JJ, White TJ (eds) PCR protocols: a guide to methods and applications. Academic Press, New York, p 315-324

Submitted: May 12, 2009; Accepted: December 9, 2009 Proofs received from author(s): January 16, 2010 